\title{
Determinan FDI Jepang di ASEAN
}

\author{
Cynthia Yohanna ${ }^{1}$, Rosanto Dwi Handoyo ${ }^{2}$ \\ Mahasiswa Program Studi Magister Ilmu Ekonomi, Universitas Airlangga, Dosen Fakultas Ekonomi dan \\ Bisnis, Universitas Airlangga \\ cynthia.swd@gmail.com
}

\begin{abstract}
Abstrak
Bangkitnya krisis ekonomi global membuat pergeseran pusat gravitasi ekonomi global dari negara-negara industrial ke negara berkembang, khususnya negara-negara di wilayah ASEAN. Salah satu penggerak pertumbuhan ekonomi adalah FDI (Foreign Direct Investment) atau investasi langsung asing. ASEAN sendiri merupakan destinasi utama Jepang untuk ekspansi kegiatan bisnis. Maka dari itu perlu adanya analisis determinan FDI untuk mengkaji karakteristik investasi Jepang di ASEAN yang dibantu dengan menggunakan model gravitasi dengan memakai estimasi Pooled Least Square.
\end{abstract}

Kata kunci: FDI, ASEAN, GDP, Determinan, Jarak

\section{Abstract}

The rise of the global economic crisis make a shift the center of gravity global economic of the industrial countries to developing countries, especially in the ASEAN countries. Foreign Direct Investment is to be a stimulant for economic growth. ASEAN is a main tourism destination japan to expand business. Therefore need to analyses determinan FDI to assess characteristic of japanese investment in ASEAN assisted by use the model of gravity with wearing estimation the pooled least square.

\section{Keywords: FDI, ASEAN, GDP, Determinan, Distance}

\section{PENDAHULUAN}

Pertumbuhan ekonomi di negara-negara ASEAN tentu tidak lepas dari kegiatan ekonomi yang membutuhkan skala besar. Investasi yang berpusat pada penambahan barang modal yang digunakan di dalam proses produksi untuk menghasilkan barang atau jasa untuk masa yang akan datang sangat diperlukan di dalam kegiatan ekonomi. Demikian di dalam praktiknya seringkali dihadapkan pada hambatan baik itu keterbatasan sumber daya manusia, modal dan faktor-faktor produksi lainnya. Oleh karena itu, transfer barang/jasa antar negara yang memiliki keunggulan komparatif sangat diperlukan. Salah satunya dapat melalui perdagangan internasional dengan instrumen penanaman modal asing langsung atau biasa disebut Foreign Direct Investment (FDI).

FDI sendiri bagi negara ASEAN merupakan alternatif sumber dana pembangunan yang relatif aman dibandingkan dengan pinjaman luar negeri. Selain itu, FDI juga dipercaya dapat menjamin kelangsungan pembangunan dibandingkan dengan aliran modal portofolio. Hal ini berbeda dengan pinjaman luar negeri yang memiliki konsekuensi dimana negara penerima pinjaman harus membayar jumlah pokok dirambah bunga pinjaman apapun kondisinya (Prasmala,2005). Berkaitan dengan hal tersebut, banyak negara yang mulai membenahi beberapa hal yang menjadi pull factors peneriman modal asing. Pull factors FDI yang dimaksud seperti kondisi pasar, ketersediaan sumber daya, daya saing negera, kebijakan yang terkait dengan perdagangan dan industri serta kebijakan liberalisasi FDI. Beberapa negara ASEAN bahkan menawarkan kemudahan kepada para investor asing berupa tax holiday, ketersediaan infrastruktur, dan pembebasan bea masuk.

Kunci pull factors kawasan ASEAN lainya adalah pertumbuhan populasi yang pesat. Kelompok usia produktif yakni dari 15 hingga 64 tahun di Kamboja, mencapai 14 juta atau 6,8 persen dari jumlah total penduduk. Menurut perkiraan Bank of America Merrill Lynch, pada 2010-2020, populasi kelompok usia produktif di Filipina akan meningkat 31,3 persen, atau mencapai 75 juta orang. Sedangkan di Malaysia akan meningkat 18,7 persen, mencapai 22 juta orang. Populasi kelompok usia produktif di Indonesia diperkirakan akan meningkat 11,2 persen, atau mencapai 180 juta orang. Jumlah populasi tersebut di negara ASEAN akan mencapai puncaknya pada 2042.

Pertumbuhan populasi di negara ASEAN akan menguntungkan berbagai industri padat karya. Peningkatan jumlah tenaga kerja yang diiringi dengan peningkatan pendapatan, jelas akan meningkatkan potensi negara-negara di Asia Tenggara. Peningkatan potensi di negara ASEAN dapat menjadikan ASEAN 
sebagai pasar dengan skala yang besar dengan konsumen terbesar di dunia. Jika kedua hal itu terbentuk, maka sangat mungkin untuk ASEAN menjadi pusat riset dan pengembangan dunia, pemilik sumber daya alam terbanyak di dunia, dan sumber investasi yang paling kaya di dunia. Alasan inilah yang membuat jumlah FDI yang mengalir di ASEAN meningkat.

Menurut The Japan Bank for International Cooperation (JBIC) sejak adanya ASEAN free trade agreements (AFTA) di tahun 1993 dan keenam negara ASEAN menghapuskan kebijakan tarif di tahun 2010, ada kenaikan trend perusahaan Jepang berinvestasi di negara ASEAN. Tentunya hal ini tak lepas dari kenaikan pasar domestik ASEAN yang didukung oleh konsumen kelas menengah dan kenaikan pendapatan. Oleh karena itu, tak sedikit negara-negara di ASEAN dijadikan basis produksi dan penjualan bagi perusahaan jasa dan manufaktur Jepang. Selain itu, menurut data survei tentang ketertarikan perusahaan Jepang yang dilakukan oleh Japan External Trade Organization (JET-RO) pada tahun 2016 menunjukkan peningkatan persentase adanya perusahaan Jepang di ASEAN mencapai angka 47\% . Hal ini tentunya didukung dengan adanya Free Trade Area dan bentuk partnership lainnya di tahun 2015. Angka tersebut tergolong tinggi dibandingkan dengan data survei di tahun 2008 yang menunjukkan investor Jepang di ASEAN hanya 18\%. Selama ini Singapura sebagai negara penerima FDI Jepang terbesar di ASEAN, diikuti oleh Thailand, Indonesia, Malaysia, Filipina dan Vietnam. Mengacu pada hal tersebut berdasarkan survei yang dilakukan oleh The Japan Bank for International Cooperation (JBIC) di 2016, ada beberapa hambatan FDI di negara-negara tersebut. Seperti kenaikan cost labor (upah) disamping minimnya tenaga kerja profesional, birokrasi pemerintah yang kurang memadai, infrastruktur yang masih terbelakang dibandingkan Jepang serta jarak antar negara yang berpengaruh pada biaya transportasi yang dikeluarkan. Oleh karena itu, salah satu cara untuk memprediksi pola dalam kegiatan perdagangan internasional adalah dengan menggunakan pendekatan gravitasi. Pendekatan tersebut diyakini mampu melihat pola interaksi atau keterkaitan antar wilayah yang memiliki daya tarik tertentu. Misalnya saja jarak antar wilayah, pemusatan kegiatan atau potensi sumber daya, dan aglomerasi penduduk.

Salah satu pentingnya FDI adalah sebagai sumber pembiayaan pembangunan negara, maka ada beberapa alasan yang menjadi dasar di dalam penulisan studi ini seperti (1) adanya perkembangan FDI Jepang ke ASEAN yang mengalami peningkatan dari 10 tahun terakhir per kawasan, sehingga perlu pengkajian mengenai karakteristik FDI Jepang yang masuk dan keluar ASEAN (2) Investasi di negara ASEAN merupakan investasi yang sangat menjanjikan terlebih lagi ASEAN mulai membuka diri akan adanya investasi asing langsung, sehingga perlu untuk diketahui apakah FDI menghasilkan produk yang lebih unggul atau sebaliknya (3) FDI mampu mempercepat pertumbuhan ekonomi negara host country, dan (4) FDI mampu membentuk daya saing negara host country sehingga memiliki keunggulan komparatif di dalam kegiatan ekspor impor.

Penelitian terdahulu yang dilakukan oleh Kwan, Qiu (2010) dalam penelitian yang berjudul "The ASEAN+3 Trading Bloc" membahas tentang hubungan FDI secara vertikal antara ASEAN5 (Indonesia, Malaysia, Filipina, Singapura, dan Thailand) dengan Jepang dan Korea melalui variabel Gross Domestic Product, Openness, Jarak, dan Populasi selama periode 1979-1988 dengan menggunakan analisis OLS. Penelitian ini dikhususkan membahas mengenai determinasi FDI Jepang di negara ASEAN dengan periode 2000-2015. Penelitian ini diharapkan mampu menangkap fenomena FDI Jepang di wilayah ASEAN dengan menggunakan model gravitasi dengan estimasi yang dilakukan secara Pooled Least Square yang nantinya menghasilkan faktor apa saja yang mampu menjadi daya tarik FDI Jepang di negara ASEAN.

\section{KAJIAN PUSTAKA \\ Foreign Direct Investment (FDI)}

Foreign Direct Investment (FDI) adalah investasi riil dalam bentuk pendirian perusahaan, pembangunan pabrik, pembelian barang modal, tanah, bahan baku, dan persediaan oleh investor asing dimana investor tersebut terlibat langsung dalam manajemen perusahaan dan mengontrol penanaman modal tersebut. FDI ini dapat dimulai dengan pendirian cabang perusahaan atau pembelian saham mayoritas dari suatu perusahaan, biasanya dibidang manufaktur, industri pengolahan, ekstrasi pengolahan, ekstrasi sumber alam, industri jasa dan sebagainya.

Pada dasarnya FDI dapat dilihat dari dua sudut pandang, yaitu inward FDI dan outward FDI. Definisi dari inward FDI adalah ketika suatu perusahaan berinvestasi atau memulai operasional perusahaannya di negara (host-country) yang berbeda dengan negara asalnya (home-country). Sementara itu, outward FDI adalah ketika perusahaan domestik berekspansi dan melakukan operasional perusahaannya di negara lain, baik dalam bentuk investasi baru (greenfield investment), penggabungan dan pengambilalihan usaha (merger and acquisition), atau bentuk ekspansi usaha lain yang memanfaatkan fasilitas di negara tujuan (host-country).

Foreign Direct Investment meliputi investasi ke dalam aset-aset secara nyata berupa pembangunan pabrik-pabrik, pengadaan berbagai macam barang modal, pembelian tanah untuk keperluan produksi, pembelanjaan berbagai peralatan inventaris, dan sebagainya (Salvatore, 1997). Caranya dengan si penanam modal membeli perusahaan di luar negeri yang sudah ada atau menyediakan modal untuk membangun perusahaan baru di sana atau membeli sahamnya sekurangnya $10 \%$. 
Biasanya, FDI terkait dengan investasi aset-aset produktif, misalnya pembelian atau konstruksi sebuah pabrik, pembelian tanah, peralatan atau bangunan; atau konstruksi peralatan atau bangunan yang baru yang dilakukan oleh perusahaan asing. Penanaman kembali modal (reinvestment) dari pendapatan perusahaan dan penyediaan pinjaman jangka pendek dan panjang antara perusahaan induk dan perusahaan anak atau afiliasinya juga dikategorikan sebagai investasi langsung. Kini mulai muncul corakcorak baru dalam FDI seperti pemberian lisensi atas penggunaan teknologi tinggi.

Selain itu, sektor publik juga ikut berperan penting di dalam menciptakan dan memperkuat benefit lokasi dengan menyediakan barang/jasa, mendidik tenaga kerja yang trampil, penyedia infrastruktur serta menajalankan kebijakan. Karena investor sangat memegang komitmen pemerintah atas investasi yang mereka tanamkan bersifat jangka panjang, maka pemerintah harus memastikan bahwa investasi akan aman dari eksploitasi, profit dapat ditransferkan ke luar negeri dan negara dipastikan memiliki kondisi ekonomi dan politik yang stabil. Kedekatan geografis dengan ekonomi yang besar dan sedang bertumbuh akan lebih menarik lagi bagi investor asing.

Penelitian ini mengacu pada teori dan model yang menentukan adanya FDI. Pertama, teori O-L-I (ownership - location - internalization) yang menjelaskan alasan suatu perusahaan melakukan kegiatan FDI. Kedua, model gravitasi yang digunakan untuk mengidentifikasi faktor pendorong dan penarik FDI.

\section{Hubungan Produk Domestik Bruto(PDB) dengan FDI}

Untuk menentukan PDB terdapat tiga cara yang berbeda namun ketiga cara tersebut masing-masing harus memberikan hasil yang sama. Ketiga cara tersebut antara lain pendekatan produk (atau output), pendekatan pendapatan, dan pendekatan pengeluaran. Dari segi pendekatan pengeluaran, pendapatan nasional adalah jumlah pengeluaran yang dilakukan oleh seluruh sektor di dalam suatu negara. Sektorsektor tersebut adalah sektor rumah tangga, sektor badan usaha, sektor pemerintahan dan sektor perdagangan internasional. Pengeluaran sektor rumah tangga dicerminkan oleh konsumsi masyarakat, pengeluaran sektor badan usaha dicerminkan oleh investasi yang dilakukan oleh perusahaan-perusahaan., pengeluaran sektor pemerintah dicerminkan oleh pengeluaran pemerintahan, sedangkan pengeluaran perdagangan dengan luar negeri tercermin dari selisih antara ekspor dan impor negara yang bersangkutan. Model gravitasi telah diterapkan dalam berbagai penelitian empiris termasuk migrasi, hak paten, perdagangan internasional dan FDI. Hal tersebut tercerminkan oleh pengeluaran pemerintahan, sedangkan pengeluaran perdagangan dengan luar negeri tercermin dari selisih antara ekspor dan impor negara yang bersangkutan.

Adapun persamaan identitas untuk menghitung pendapatan nasional dari sisi peneluaran adalah sebagai berikut:

$$
Y=C+I+G+(X-M)
$$

Penjelasannya adalah Y merupakan Produk Domestik Bruto; C merupakan konsumsi; I merupakan investasi; $\mathrm{G}$ merupakan pengeluaran pemerintah; $\mathrm{X}$ adalah ekspor dan $\mathrm{M}$ adalah impor. Besarnya produk domestik bruto suatu negara tiap tahun merupakan salah satu indikator pengukuran ekonomi mengenai besarnya pasar yang dalam jangka panjang akan lebih besar menarik investasi asing langsung (Prakosa, 2003).

Secara empiris, PDB suatu negara menunjukan pengaruh yang beragam terhadap keberadaan FDI. Penelitian sebelumnya, yang dilakukan oleh Sarwedi (2002) dalam tulisannya yang berjudul "Investasi Asing Langsung dan Faktor yang Mempengaruhinya" menunjukan adanya hubungan positif antara PDB dengan FDI. Sebaliknya, tulisan yang berjudul "Analisis Faktor-Faktor yang Mempengaruhi Penanaman Modal Asing di Indonesia" oleh Tri Rahayu (2010) menemukan bahwa produk domestik bruto mempunyai pengaruh negatif dan signifikan terhadap investasi asing langsung.

Sadono Sukirno (2002) dalam bukunya menyatakan bahwa dengan tingkat pendapatan nasional yang tinggi akan mempengaruhi pendapatan masyarakat, dana selanjutnya pendapatan masyarakat yang tinggi tersebut akan memperbesar permintaan terhadap barang-barang dan jasa-jasa. Maka keuntungan perusahaan akan bertambah tinggi dan ini akan mendorong dilakukannya lebih banyak investasi. Ukuran ekonomi dalam hal PDB dan PDB per kapita memiliki pengaruh signifikan pada FDI (Bakir dan Alfawaz, 2009).

Namun, Rahayu (2010) memiliki pendapat lain, PDB berpengaruh negatif terhadap FDI. Faktor yang menjadi penyebab tidak berpengaruhnya PDB terhadap FDI dalam jangka panjang adalah karena masuknya dana dalam bentuk dollar, maka rupiah akan terdepresiasi dan kegiatan ekonomi menurun dan nilai produk domestik bruto juga akan menurun, juga karena adanya transfer dana hasil keuntungan dari dalam negeri ke luar negeri sehingga dana tersebut tidak bisa digunakan lagi untuk investasi (reinvestasi), selain itu juga disebabkan karena teknologi dan sistem manajemen yang digunakan sudah usang.

\section{Hubungan Distance dengan FDI}

Jarak mengacu pada mudah atau sulitnya barang, jasa, modal, tenaga kerja, informasi dan ide-ide untuk meintasi ruang. Hal itu akan mengukur seberapa mudah arus modal, mobilitas tenaga kerja, distribusi 
barang dan layanan yang disampaikan anatara dua lokasi serta ciri-ciri fisik geografi yang memisahkan mereka, hubungan tersebut bukanlah hal yang mudah untuk dipahami. Salah satu alasannya adalah bahwa jarak untuk pertukaran barang berbeda untuk migrasi orang.

Untuk perdagangan barang dan jasa, jarak menangkap waktu dan biaya moneter. Penempatan dan kualitas infrastruktur transportasi dan ketersediaan transportasi secara dramatis dapat mempengaruhi jarak ekonomi antara dua daerah. Arus perdagangan internasional akan sangat dipengaruhi oleh pendapatan negara yang bersangkutan dan jarak antar negara tentunya berpengaruh sebagai pendekatan biaya transportasi. Pendapatan antar negara tentunya berpengaruh secara positif terhadap arus perdagangan, dimana semakin besar pendapatan kedua negara maka arus perdagangan akan semakin tinggi dan sebaliknya, semakin jauh jarak di antara negara menandakan biaya transportasi akan semakin tinggi yang pada akhirnya berimplikasi menurunkan arus perdagangan (Kartini, 2007). Hal ini berhubungan terbalik dengan tulisan "Free Trade Agreement in East Asia" oleh Yang dan Handayanto (2013) yang menyatakan bahwa jarak tidak mempengaruhi hubungan perdagangan antar negara di Asia Timur, seperti sedikitnya aktivitas perdagangan antar China, Jepang dan Korea karena kesamaan sumber daya dan adanya perbedaan budaya.

Teori gravitasi berpendapat bahwa jarak akan menentukan besar FDI dan volume perdagangan antar negara. Semakin jauh jarak, maka FDI dan volume perdagangan akan semakin kecil karena ada hambatan transportasi yang memerlukan tambahan biaya. Namun ada yang berpendapat sebaliknya, bahwa jarak tidak berpengaruh terhadap FDI. Koefisien jarak yang negatif dan signifikan, menyiratkan bahwa biaya transaksi yang lebih rendah menyebabkan arus masuk FDI lebih tinggi (Ismail, dkk, 2009). Variabel jarak tidak signifikan dalam menentukan arus FDI (Amir dan Torki, 2009).

\section{Hubungan Populasi dengan FDI}

Salah satu faktor penentu potensial yang penting dari FDI adalah penduduk negara tuan rumah. Namun demikian, tampaknya sering diabaikan oleh penelitian empiris mengenai arus masuk FDI. Menariknya, peran penduduk dalam pertumbuhan ekonomi telah menjadi bahan perdebatan di kalangan ekonom untuk waktu yang cukup lama. Salah satu teori yang paling berpengaruh Populasi diusulkan oleh Thomas Robert Malthus (1766-1834) yang menyatakan bahwa jumlah penduduk yang besar adalah masalah bagi negara-negara berkembang. Dia percaya bahwa pasokan makanan akan meningkat pada tingkat aritmatika sementara penduduk, jika tetap dibiarkan, akan meningkat pada tingkat geometris (Malthus, 1992). Alasan lambatnya peningkatan produksi pangan mungkin karena kelangkaan lahan dan hukum berkurangnya marjinal kembali ke buruh dan lahan pertanian (Aziz dan Makkawi, 2012). Malthus juga percaya bahwa akan ada ketegangan konstan antara populasi dan sumber daya yang tersedia, dan bahwa akan ada sistem yang mengatur sendiri fluktuasi populasi sendiri (Caldwell, 1998). Ini berarti negara-negara dengan populasi besar tidak diharapkan untuk menyaksikan setiap pertumbuhan ekonomi.

Nagarajan berpendapat bahwa teori klasik (Malthusian) gagal karena tidak mempertimbangkan efek potensi teknologi (Aziz dan Makkawi, 2012). Kemajuan teknologi dapat moderat atau bahkan mengimbangi efek negatif dari pertumbuhan penduduk, dengan menambah kualitas dan produktivitas faktor produksi, tanah, tenaga kerja dan modal dan juga dapat memberikan kontribusi terhadap pertumbuhan pendapatan. Dalam hal ini ekonomi global, peran FDI tidak bisa terganggu dan karena itu, ukuran populasi mungkin tidak diabaikan oleh perusahaan multinasional karena mereka berusaha untuk meningkatkan keuntungan mereka di pasar internasional. Populasi besar memberikan pasar yang besar untuk produk dan layanan yang ditawarkan oleh perusahaan multinasional, memiliki tenaga kerja yang besar dan basis keterampilan yang luas.

Penelitian yang dilakukan oleh Aziz dan Makkawi (2012) mengenai hubungan antara ukuran penduduk dan arus masuk FDI di beberapa negara Asia menunjukan bahwa populasi berhubungan secara positif dan signifikan terhadap FDI. Perusahaan multinasional mungkin mempertimbangkan penduduk suatu negara sebagai faktor dalam keputusan mereka untuk berinvestasi di suatu negara karena ada beberapa faktor yang tidak dapat diabaikan, seperti populasi yang besar akan memiliki consumption yang tinggi dan jelas akan berdampak pada demand yang tinggi pula. Penelitian terdahulu oleh Kwan dan Qiu (2010) juga menunjukan hal yang sama bahwa populasi berhubungan positif terhadap FDI.

\section{Hubungan Keterbukaan dengan FDI}

Dalam teori perdagangan internasional dijelaskan bahwa ketika perekonomian suatu negara semakin terbuka dan terintegrasi dengan perekonomian global, maka mobilitas faktor-faktor produksi akan semakin tinggi. Sementara dalam teori-teori keuangan internasional, ketika perekonomian suatu negara semakin terintegrasi dengan perekonomian global, maka mobilitas dari modal akan semakin tinggi (perfect capital mobility). Ketika kondisi perfect capital mobility hampir dapat dicapai, maka aliran modal dalam bentuk FDI akan semakin meningkat.

Secara empiris, Chiou Wei and Zhu (2007) menemukan bahwa keterbukaan ekonomi bukan merupakan faktor yang signifikan terhadap FDI. Hal ini bertentangan dengan teori dan beberapa penelitian lainnya, seperti studi yang dilakukan Pantelidis dan Kyrkilis (2005) menunjukkan ada hubungan positif yang 
signifikan antara keterbukaan ekonomi dengan FDI. Hasil penelitian terdahulu oleh Kwan dan Qiu (2010) juga menunjukan hubungan positif antara keterbukaan dengan FDI.

Keterbukaan merupakan jumlah ekspor dan impor barang dan jasa yang diukur sebagai dari PDB. Dalam dunia yang semakin global saat ini, ekspor dan impor agregat kunci dalam analisis situasi ekonomi suatu negara. Setiap kali ekonomi melambat atau mempercepat, semua negara lain berpotensi terkena dampak. Barang (perdagangan barang) mencerminkan sebagian besar impor dan ekspor, dan ini umumnya baik tertutup dan mampu komparatif baik di negara-negara, meskipun perbedaan antara total impor dan ekspor barang yang diperdagangkan di tingkat global mengungkapkan pengukuran yang dalam prakteknya tidak sepele. Pertumbuhan perdagangan melalui internet telah meningkat kesulitan dalam pengukuran.

Ekspor barang dan jasa merupakan penjualan, barter atau hadiah atau hibah, barang dan jasa (termasuk dalam batas produksi PDB) dari warga untuk non-penduduk. Tidak ada konsensus teoritis tentang peran ekspor dalam pertumbuhan ekonomi,hal ini memang menjadi salah satu isu yang masih diperdebatkan dalam pertumbuhan dan literatur pembangunan. Pada kerangka neraca nasional pandangan Keynesian, net ekspor merupakan permintaan eksternal untuk output suatu negara. Ekspor diharapkan dapat meningkatkan pertumbuhan ekonomi suatu negara apabila terjadi surplus dan meningkatkan produktifitas.

Impor suatu negara merupakan fungsi dari pendapatan nasionalnya, dan cenderung berkorelasi positif. Semakin besar pendapatan nasional suatu negara, semakin besar pula kebutuhan atau hasratnya akan barang-barang dari luar negeri, sehingga nilai impornya semakin besar. Faktor-faktor yang mempengaruhi impor antara lain:

a) Kekurangan produksi, suatu negara yang memiliki kebutuhan akan suatu barang dan jasa melebihi kemampuan produksi agregatnya akan melakukan impor barang.

b) Stabilitas harga, suatu perekonomian yang sudah mampu memenuhi kebutuhan sendiri dengan produksi agregatnya, membutuhkan impor ketika terjadi fluktuasi harga pada barang dan jasa tertentu, terutama produk pertanian yang suplainya tergantung pada musim panen.

c) Ongkos produksi, suatu perekonomian yang belum memiliki teknologi dan faktor produksinya terbatas akan mengimpor barang dan jasa karena ongkos produksi apabila diproduksi didalam negeri akan jauh lebih tinggi dari pada impor.

d) Komponen Barang dan Jasa, suatu perekonomian yang sedang berkembang, memiliki kebutuhan akan impor barang untuk memproduksi suatu barang yang belum semua komponennya dapat dibuat sendiri, sementara barang tersebut sudah menjadi kebutuhan dalam masyarakat perekonomian tersebut.

e) Barang modal, terutama untuk perekonomian yang sedang berkembang, membutuhkan barang-barang modal untuk menghasilkan produk-produk yang menjadi kebutuhan perekonomian tersebut.

Keterbukaan mungkin memiliki tanda positif terhadap FDI karena perekonomian yang lebih terbuka dapat mempengaruhi arus masuk FDI yang lebih tinggi. Ditambah lagi dengan adanya perjanjian dalam perdagangan bebas seperti AFTA yang mengurangi hambatan perdagangan, terutama tarif antar negara anggota (Ismail, dkk, 2009).

\section{HIPOTESIS PENELITIAN}

Berdasarkan permasalahan yang telah diurai diatas, tujuan penelitian yang ingin dicapai dan teori yang menyangkut investasi asing langsung maka hipotesis yang diajukan dalam penelitian adalah sebagai berikut:

H1.Diduga Produk Domestik Bruto per kapita berpengaruh positif dan signifikan terhadap nilai FDI. H2.Diduga distance berpengaruh negatif dan signifikan terhadap nilai FDI.

H3.Diduga population berpengaruh positif dan signifikan terhadap nilai FDI. H4.Diduga openness berpengaruh positif dan signifikan terhadap nilai FDI.

\section{METODE PENELITIAN}

Penelitian ini menggunakan jenis penelitian kuantitatif deskriptif. Jenis penelitian ini bertujuan menggambarkan hubungan antar variabel-variabel penelitian dan menguji hipotesis yang telah dirumuskan sebelumnya.

Variabel yang digunakan dalam penelitian ini ada dua macam, yaitu variabel bebas atau variabel independen serta variable terikat atau variabel dependen. Variabel - variabel yang dimaksud adalah :

1. Foreign Direct Investment adalah arus modal internasional yang melibatkan perusahaan dari suatu negara mendirikan atau memperluas perusahaannya ke negara lain. Variabel FDI diproyeksikan dengan data net inflow FDI dalam bentuk satuan US\$ yang diperoleh dari ASEAN Secretariat dan data ditransformasikan ke dalam bentuk logaritma.

2. Produk Domestik Bruto dalam penelitian ini menggunakan PDB per kapita, yang artinya PDB di setiap negara ASEAN dibagi dengan jumlah penduduk pertengahan tahun, dihitung tanpa depresiasi aset dan degradasi sumber daya alam. Data GDP digunakan dalam bentuk US\$ yang diperoleh dari World Bank dan ditransformasikan ke dalam bentuk logaritma. 
3. Populasi adalah jumlah penduduk di setiap negara ASEAN yang dinyatakan dalam satuan jiwa. Data populasi diperoleh dari World Bank dan ditransformasikan ke dalam bentuk logaritma

4. Jarak diukur dari setiap ibukota negara ASEAN dengan ibukota Jepang yang dinyatakan dalam satuan $\mathrm{km}$. Data diperoleh dari Global Distance Calcualtor dan ditransformasikan ke dalam bentuk logaritma.

5. Keterbukaan adalah tingkat keterbukaan suatu negara terhadap perdagangan international. Variable Openness yang dimaksud adalah penjumlahan volume ekspor dan impor dengan GDP nominal suatu negara yang dinotasikan ke dalam rasio (Sachs and Warner, 1995). Data tersebut diambil dari World Bank yang kemudian diolah dengan menggunakan rumus sebagai berikut :

TOP : Trade Openess

$$
\mathrm{TOP}=\frac{\left(V O L_{x^{i}}+V O L_{m^{i}}\right)}{G D P_{i}}
$$

$\mathrm{VOL}_{\mathrm{x}}{ }^{i}$ : : volume ekspor di negara i (ASEAN) dalam bentuk satuan US\$

$\mathrm{VOL}_{m}{ }^{i}$ : volume impor di negara i (ASEAN) dalam bentuk satuan US\$

GDP $_{\mathrm{i}} \quad$ : Gross Domestic Product di negara i (ASEAN) dalam bentuk satuan US\$

Penelitian ini memakai jenis data kuantitatif yang termasuk dalam data sekunder. Data sekunder yang dimaksud adalah data yang diperoleh melalui penelitian tidak langsung. Jenis data yang digunakan untuk metode data panel adalah cross section dan time series. Data cross section yaitu negara ASEAN, dan data time series adalah data variabel yang dihimpun dari tahun 2000-2015.

Penelitian ini menggunakan beberapa sumber data yang telah dipaparkan pada variabel-variabel di atas dengan menggunakan data makro yang menyatakan bahwa sesungguhnya FDI merupakan perusahaan individual. Penggunaan data makro ini dikarenakan keterbatasan dalam memperoleh data individual FDI. Penelitian ini memakai teknik analisis data yang dikembangkan oleh Kwan dan Qiu (2010). Kedua penulis tersebut menganalisis investasi Jepang ke ASEAN dengan penjabaran model sebagai berikut $: 1 \mathrm{n}($ FDlit $)=\beta 0+\beta 11 \mathrm{n}($ PDBit $)+\beta 21 \mathrm{n}($ DISTit $)+\beta 31 \mathrm{n}($ POPit $)+\gamma 1$ OPENit $+\varepsilon i$

Penelitian ini menggunakan metode regresi PLS (Pooled Least Square) panel data. Namun, sebelum melakukan estimasi dengan mengunakan panel data, perlu digunakan terlebih dahulu pengujian stasioneritas dengan panel root test yang terdiri dari uji Levin, Lin and Chu $t^{\star}, \mathrm{Im}$., Pesaran and Shin WStat,ADF- Fisher Chi-Square, PP-Fisher Chi Square.

\section{HASIL DAN PEMBAHASAN Hasil Analisis Deskripstif}

Data panel dapat diestimasi dengan menggunakan metode : Pooled Least Square (PLS), Fixed Effect Model (FEM) dan Random Effect Model (REM). Pemilihan model estimasi yang cocok dapat dilakukan dengan pengujian model. Namun, dikarenakan penelitian ini menggunakan variabel jarak sebagai salah satu variabel independen. Maka akan terjadi tidak adanya variabilitas time series yang mana nilai jarak akan berlaku sama dari waktu ke waktu. Sehingga model yang dapat digunakan hanya Pooled Least Square (PLS).

a) T test atau uji hipotesis tentang koefisien individu secara parsial, khususnya untuk variabel penjelas terhadap variabel dependen. Untuk uji hipotesis, probabilitas (t-stat) lebih kecil dari tingkat signifikansinya sebesar $1 \%, 5 \%$, atau

b) $10 \%$, maka hipotesis null nya ditolak. Hal ini mengimplikasikan bahwa independen variabel tersebut dipengaruhi oleh variabel dependen secara parsial (Gujaratidan Porter, 2009). Estimasi ini berfungsi untuk menghasilkan interpretasi yang jelas untuk mengungkap pola perdagangan.

c) Koefisien determinasi atau adjusted $R^{2}$ mengukur sejauh mana hubungan regresi yang cocok dengan data yang ada.

Adapun asil pengolahan estimasi PLS dapat dilihat pada Tabel 1

\begin{tabular}{|l|l|l|l|l|}
\hline \multicolumn{4}{|l|}{ R- squared } & 0,672808 \\
\hline \multicolumn{4}{|l|}{ Prob (F-statistics) } & 0,000000 \\
\hline Numb. Of Observation & 144 \\
\hline Variabel & Coef & Std. Error & t-Statistic & Prob \\
\hline GDP & 1,522396 & 0,143944 & 10,57632 & 0,0000 \\
\hline DIST & $-0,572495$ & 0,954487 & $-0,599793$ & 0,5496 \\
\hline POP & 1,283498 & 0,098555 & 13,02314 & 0,0000 \\
\hline OPEN & 0,006405 & 0,002008 & 3,189335 & 0,0018 \\
\hline C & $-11,16099$ & 7,649566 & $-1,459036$ & 0,1468 \\
\hline
\end{tabular}

Sumber : Hasil Estimasi Eviews8, 2018 
Jadi persamaan regresi pada penelitian ini adalah menggunakan model PLS dengan persamaan sebagai beriut :

$\mathrm{FDI}=-11,16099+1,522396 *$ GDP $-0,572495^{*} \mathrm{DIST}+1,283498 * \mathrm{POP}+0,006405$ * OPEN

Persamaan diatas secara teoritis nilai konstanta $-11,16099$ memiliki arti bahwa FDI akan memiliki nilai 11,16099 ketika GDP, Distance, Populasi dan Openness benilai 0, hal ini berlaku meskipun secara ekonomi tidak realistis.

Berdasarkan hasil estimasi PLS pada Tabel 1 menunjukkan bahwa masing-masing variabel bebas memiliki nilai yang bervariasi. Berikut ini penjelasan masing-masing model :

a. Koefisien regresi variabel GDP terhadap FDI adalah sebesar 1,522396 dengan nilai probabilitas sebesar 0,000 yang mana lebih kecil dari a $(1 \%, 5 \%$ dan $10 \%)$. Hasil estimasi menunjukkan signifikan dan mempengaruhi variabel dependen. Hal ini sesuai dengan hipotesis yang dibentuk, yaitu Produk Domestik Bruto per kapita berpengaruh positif dan signifikan terhadap nilai FDI Jepang di ASEAN.

b. Koefisien regresi variabel Population terhadap FDI adalah sebesar 1,283498 dengan nilai probabilitas sebesar 0,000 yang mana lebih kecil dari $\alpha(1 \%, 5 \%$ dan $10 \%)$. Hal ini sesuai dengan hipotesis yang dibentuk, yaitu Population berpengaruh positif dan signifikan terhadap nilai FDI Jepang di ASEAN.

c. Koefisien regresi variabel Openness terhadap FDI adalah sebesar 0,006405 dengan nilai probabilitas sebesar 0,0018 yang mana lebih kecil dari $\alpha(1 \%, 5 \%$ dan $10 \%)$. Hal ini sesuai dengan hipotesis yang dibentuk, yaitu Openness berpengaruh positif dan signifikan terhadap nilai FDI Jepang di ASEAN.

d. Koefisien regresi variabel Distance terhadap FDI adalah senilai $-0,572495$ dengan nilai probabilitas sebesar 0,5496 yang mana lebih besar dari a (1\%, 5\% dan 10\%). Sehingga Distance tidak dapat dipakai sebagai estimator yang signikan dan tidak mempengaruhi variabel dependen. Hal ini tidak sesuai dengan hipotesis yang dibentuk

\section{Pembahasan}

Hasil regresi panel dengan menggunakan metode PLS menunjukkan hasil bahwa GDP memiliki dampak positif dan signifikan terhadap FDI. Beberapa hasil penelitian seperti Yati.,et.al (2007) menyatakan adanya hubungan antara GDP dan FDI. Pertumbuhan ekonomi yang tinggi mampu menjadi daya tarik utama aliran FDI ke wilayah suatu negara, terutama terkait dengan motif perluasan target pasar. Hal senada juga dikemukakan oleh D. Kyrkilis (2011) yang menyatakan GDP berhubungan dengan. Beberapa penelitian yang mengunakan GDP sebagai determinan FDI seperti Chakrabarti (2001), Prakosa (2003), Sarwedi (2002), Kwan (2010), dan Sadono (2002) mengemukakan bahwa GDP mendorong masuknya FDI.

Penelitian yang dilakukan oleh Aziz dan Makkawi (2012) mengenai hubungan antara ukuran penduduk dan arus masuk FDI di beberapa negara Asia menunjukan bahwa populasi berhubungan secara positif dan signifikan terhadap FDI. Perusahaan multinasional mungkin mempertimbangkan penduduk suatu negara sebagai faktor dalam keputusan mereka untuk berinvestasi di suatu negara karena ada beberapa faktor yang tidak dapat diabaikan, seperti populasi yang besar akan memiliki consumption yang tinggi dan jelas akan berdampak pada demand yang tinggi pula. Penelitian terdahulu oleh Kwan dan Qiu (2010) juga menunjukan hal yang sama bahwa populasi berhubungan positif terhadap FDI.

Berdasarkan hasil penelitian regresi panel dengan menggunakan metode PLS menunjukkan bahwa populasi berpengaruh positif dan signifikan terhadap FDI. Beberapa penelitian terdahulu menyebutkan bahwa populasi memiliki dampak yang positif dan signifikan terhadap FDI, yang nantinya akan meningkatkan pertumbuhan ekonomi (Alfaro et al., 2004, Beuglesdijk et al., 2008, Yao dan Wei, 2007). Artinya bertambahnya penduduk di suatu negara mampu menjadi faktor yang menentukan apakah perusahaan multinasional lain dari negara host country memutuskan untuk berinvestasi di negara tersebut.

Populasi suatu negara mampu menunjukkan potensi pasar negara tersebut dalam kegiatan ekonomi global. Bertambahnya populasi maka semakin tinggi konsumsi suatu negara sehingga dapat memicu kegiatan ekonomi yang semakin tinggi. Hal ini yang jug dialami oleh ASEAN. Meningkatnya kelas menengah di kalangan generasi muda ASEAN juga menjadi pangsa pasar konsumsi terbesar. Keterbukaan perdagangan (Openness ) erat hubungannya dengan kegiatan ekspor dan impor. Menurut Freud dan Bolaky (2008) dan Chang et al. (2009) menunjukkan Openness berdampak positif dalam segi pendapatan negara dan hubungan positif antar negara dalam bidang politik.Secara empiris, Chiou Wei and Zhu (2007) menemukan bahwa keterbukaan ekonomi bukan merupakan faktor yang signifikan terhadap FDI. Hal ini bertentangan dengan teori dan beberapa penelitian lainnya, seperti studi yang dilakukan Pantelidis dan Kyrkilis (2005) menunjukkan ada hubungan positif yang signifikan antara keterbukaan ekonomi dengan FDI. Hasil penelitian terdahulu oleh Kwan dan Qiu (2010) juga menunjukan hubungan positif antara keterbukaan dengan FDI.

Berdasarkan hasil penelitian menunjukkan bahwa openness berpengaruh positif dan signifikan terhadap FDI. FDI yang masuk diharapkan mampu menjadi transfer teknologi, transformasi ekonomi dan peningkatan teknologi. Hal ini dikarenakan adanya hubungan antara perusahaan multinasional dengan perusahaan lokal yang turut serta memajukan UMKM domestik. Penelitian yang dilakukan oleh Blostrom dan Kokko, 1997; Yati et.al., 2002 percaya bahwa dampak dari adanya wilayah ekonomi yang terintegrasi pada kegiatan FDI, tenyata sangat bergantung pada struktur atau motif dari FDI itu sendiri. FDI Horizontal terjadi 
ketika suatu perusahaan melakukan relokasi produksi ke luar negeri dikarenakan biaya produksi yang lebih murah di negara lain daripada ekspor produk domestik dan membayar tarif berlebih. Secara umum, perusahaan lebih banyak memproduksi produk yang sama dengan memakai banyak macam alat produksi dan masing-masing alat produksi tersebut melayani permintaan pasar domestik yang beragam. Vertikal FDI terjadi ketika perusahaan melakukan relokasi pada proses dan alat produksi di suatu negara dengan memakai sejumlah tenaga kerja tertentu dan insfrastruktur negara tersebut untuk memeperoleh keuntungan dari segi harga.

Pada umumnya, kegiatan perdagangan antar negara memiliki keterbatasan pada transportation cost. Jarak yang cukup jauh diantara negara yang melakukan FDI tidak hanya mempengaruhi dari segi biaya saja tetapi meningkatkan perbedaan budaya. Berdasarkan hasil penelitian menunjukkan bahwa jarak tidak berpengaruh positif dan signifikan terhadap FDI. Hal ini dikarenakan keunggulan geografis masing-masing negara yang berbeda. Indonesia, memiliki posisi yang startegis dengan didukung kekayaan alam yang melimpah dan jumlah penduduk yang besar sehingga mampu memainkan peran ganda sebagai basis produksi bagi konsumsi domestik dan ekspor, Singapura menurut ease of doing business merupakan salah satu negara yang mudah untuk melakukan bisnis. Hal ini dikarenakan adanya kemudahan memberikan pinjaman pada investor asing, regulasi yang sederhana, keringanan pajak dan industri properti yang sangat baik. Beberapa faktor tersebut yang mampu menarik FDI masuk ke Singapura. Begitu juga dengan FDI Jepang yang masuk di Singapura sekitar 2.357 juta dollar di tahun 2015.

Malaysia yang memiliki jarak yang tidak jauh dari Indonesia menjadi destinasi FDI Jepang khususnya di bidang komunikasi. Malaysia dijadikan salah satu negara yang memiliki pemancar komunikasi di ASEAN. Berbeda dengan negara Kamboja, Laos dan Myanmar. Ketiga negara tersebut memiliki jarak yang lebih dekat dengan Jepang namun FDI inflow yang diperoleh masih kalah bersaing dengan Singapura. Oleh karena itu, untuk menarik aliran FDI Jepang, Kamboja mampu menawarkan upah buruh yang lebih murah di tahun 2013 (Mizuho, 2017).

Berdasarkan hasil penelitian, dapat terlihat beberapa variabel yang mempengaruhi seperti GDP, Openness, dan Populasi maka dapat dikatakan bahwa FDI Jepang di ASEAN memiliki karakteristik market seeking. Hal ini dapat dijelaskan bahwa perusahaan multinasional Jepang ingin mendekatkan produk ke konsumen potensial, dan menghindari hambatan impor dengan asumsi dapat menjual produk lebih murah daripada impor. Karena market-seeking merupakan salah satu karakteristik FDI yang memberikan manfaat lebih, maka sebagai balas jasanya, host country akan mendapat teknologi baru, penciptaan lapangan kerja untuk pekerja trampil dan penambahan pajak negara.

\section{KESIMPULAN DAN SARAN \\ Kesimpulan}

Berdasarkan uraian dan pembahasan pada bab-bab sebelumnya mengenai pengaruh Gross Domestic Product, Populasi, Jarak dan Openness terhadap FDI Jepang di ASEAN periode 2000-2015. Maka berdasarkan hasil estimasi regresi PLS dan uji hipotesis yang telah dilakukan, dapat disimpulkan hal-hal sebagai berikut :

a. Hasil analisis menunjukkan GDP berpengaruh positif dan signifikan terhadap FDI. Koefisien variabel GDP menunjukkan hubungan positif yang artinya ketika GDP meningkat 1 US\$, maka FDI akan meningkat sebesar 1,522396 US\$. Sehingga hipotesis yang terbentuk sudah terpenuhi.

b. Populasi berpengaruh positif terhadap FDI yang artinya ketika Populasi meningkat 1 Jiwa, maka FDI akan meningkat sebesar 1,283498 US\$. Sehingga hipotesis yang terbentuk sudah terpenuhi.

c. Openness menunjukkan hubungan positif terhadap FDI yang artinya ketika Openness meningkat 1 satuan, maka FDI akan meningkat sebesar 0,006405 US\$. Sehingga hipotesis yang terbentuk sudah terpenuhi.

d. Distance menunjukkan hubungan negatif terhadap FDI. Sehingga hipotesis yang terbentuk tidak terpenuhi.

\section{Saran}

Berdasarkan simpulan diatas, yang menyatakan bahwa GDP, Populasi, dan Openness berpengaruh positif terhadap FDI, maka implikasi penelitian sebagai berikut:

a. Secara khusus GDP memiliki pengaruh positif dan signifikan terhadap FDI. Pertumbuhan ekonomi menjadi determinan yang kuat guna menarik investor Jepang untuk menanamkan modalnya di ASEAN. Maka upaya mendorong adanya peningkatan pertumbuhan ekonomi menjadi penting di dalam mendorong aliran FDI.

b. Populasi memilki peran ganda dalam FDI. Selain menjadi basis produksi namun juga menjadi pangsa pasar. Oleh karena itu perlu ada peningkatan keterampilan tenaga kerja yang mengadopsi teknologi tinggi guna menarik FDI manufaktur. Peningkatan dapat dilakukan dengan mengadopsi budaya kerja perusahaan multinasional supaya ASEAN sebagai tuan rumah FDI mampu memberikan produktivitas tinggi. 
c. Keterbukaan terhadap perdagangan dapat dilakukan dengan mengurangi hambatan di dalam birokrasi, peningkatan infrastruktur di bidang akses transportasi dan komunikasi serta menambah perjanjian bilateral antar negara untuk peningkayan production networking di ASEAN.

\section{Keterbatasan Penelitian}

Penelitian dan analisis pada bab-bab sebelumnya memiliki kelemahan yaitu :

a. Data FDI Jepang ke masing-masing negara ASEAN yang tidak ditemukan secara bebas di beberapa laman website resmi dunia yang mudah diakses. Serta jumlah satuan yang tidak seragam di masingmasing data yang diperoleh.

b. Analisis mengenai determinan FDI Jepang di ASEAN dapat dilakukan dengan melihat dari ketiga motif FDI seperti resource seeking, market seeking, efficiency seeking, dan strategic asset seeking. Sedangkan penelitian ini hanya membahas market seeking, dan efficiency seeking. Kedepannya diharapkan dapat membahas lebih mendalam dan secara khusus dapat memaparkan per komponen seperti reinvested earning, dan analisa kelompok multinational company dengan beberapa tambahan variable, tahun dan tempat penelitian yang diharapkan mampu menjadikan kedepannya menjadi lebih baik.

\section{DAFTAR PUSTAKA}

Alberto et.al. "Trade, Growth and the Size of Countries". Elsevier B. 2005

Anwara, S. dan L. Nguyen. 2010. Foreign Direct Investment and Economic Growth in Vietnam. Asia Pacific Business Review 16(1): 183-202.

Aziz, A. dan Makkawi, B. (2011). Relationship between Foreign Direct Investment and Country Population. International Journal of Business and Management, 7(8).

Bakir, A. dan Alfawwaz, T. (2009). Determinants of Foreign Direct Investment in Jordan. Journal International Management Review, 5(2).

Blonigen, B. A. (2005). " A Review of the Empirical Literature on FDI Determinants". Atlantic Economic Journal Vol.33.

Calvo et.al. "The ASEAN Free Trade Agreement: Impact on Trade Flows and External Trade Barriers". Policy Research Working Paper The World Bank Development Research Group Trade and Integration Team, 2009

Chiou Wei, S.Z., Zhu, Z. (2007). A Revisit to The Outward FDI Determinants: Further Evidence from Count Panel Data Models with Fixed Effects. Applied Economics Letters 14, 809-812.

Dogga S., Suresh K., Amaresh . 2014. Trade Openness, Financial Development Index and Economic Growth. Journal of Financial Economic Policy. Vol.6

Hadi, Sutrisno. (2000). Metodologi Research. Yogyakarta: Andi Yogyakarta.

Hsiao,C. 2003. Analysis of Panel Data. Edisi 2. New York: Cambridge Univ. Press.

Hsu et.al (2011). "The Effects of Outward FDI on Home Country Productivity". Journal of Chinese Economic and Foreign Trade Studies. Vol.4

Ismail, N. W., Smith, P., \& Kugler, M. (2009). The Effect of ASEAN Economic Integration on Foreign Direct Investment. Journal of Economic Integration (pp. 385-407).

Iwamoto, Manabu \& Nabeshima, Kaoru. (2012). "Can FDI promote export diversification and sophistication of host countries? : dynamic panel system GMM analysis," IDE Discussion Papers 347, Institute of Developing Economies, Japan External Trade Organization (JETRO).

Klimis V., Phuong Nhung T.N. (2016). Economic Openness and Economic Growth : A Cointegration Analysis For ASEAN-5 Countries. Journal of Applied Economics. Vietnam.

Kravis, I.B., Lipsey, R.E. (1982). The Location of Overseas Production and Production for Export by U.S. Multinational Firms. Journal of International Economics, 12, 201-223.

Krugman, Paul R. dan Maurice Obstfeld, (2009),International Economics: Theory and Policy, Eight Edition, Addison-Wesley.

Kurniati, Y.,Prasmuko, A.,Yanifitri. Determinan FDI. Working Paper Bank Indonesia 6: 1-20.

Kwan dan Qiu. 2010. The ASEAN+3 Trading Bloc. Journal of Economic Integration 25(1): 1-31.

Masahito. 2017. ASEAN as an Attractor: How Do Multinationals Look at ASEAN. Economic Research Institute for ASEAN and East Asia.

Milner C, Reed G, Talerngsri P (2004) Foreign direct investment and vertical integration of production by Japanese multinationals in Thailand. J Comp Econ 32(4):805-821

Parasmala, E. (2005). Analisis Hubungan Kausalitas Foreign Direct Investment (FDI) dengan Variabel Makroekonomi di Indonesia. Fakultas Ekonomi dan Manajemen: IPB, Bogor.

Sarwono, J. 2006. Metode Penelitian Kuantitatif dan Kualitatif. Yogyakarta: Graha IImu.

Shinta dan Triono. 2015. Pemetaan dan Determinan Intra-ASEAN Foreign Direct Investment (FDI): Studi Kasus Indonesia. Working Paper Bank Indonesia. 
Shujiro dan Waseda. 2002. Japanese Foreign Direct Investment in East Asia with Particular Focus on ASEAN4. Conference on Foreign Direct Investment: Opportunities and Challenges for Cambodia, Laos, and Vietnam.

Tamirisa, T., Natalia."Exchange and Capital Controls as Barriers to Trade". IMF working paper, 1999.

Tinbergen, J. (1962). Sharing the Word Economy : Suggestions for an International Economic Policy. Twentieth Century Fund : New York.

Yang, Ivy dan Y. J. Handayanto. (2013). Free Trade Agreement in East Asia. Social Transformation Toward sustainable Community, 57-64.

Zarzoso, Martines., Inmaculada." Gravity Model: An Application to Trade Between Regional Blocs", Atlantic Economic Journal, 2003.

Japan Trade and Investment Statistical, 2017

Japan Bank for International Cooperation, 2010

Japan Bank for International Cooperation, 2017

Mizuho Economic Outlook \& Analysis, 2017

World Development Indicator. 201 